\title{
A Case Study on Irregularities Present in Tall Building and Review of Provisions on Indian Standard
}

Ashish Poudel ${ }^{*}$

Department of Civil Engineering, Oxford College of Engineering and Management, Gandaki, Nepal

DOI: $10.36348 /$ sjce.2021.v05i01.001 $\quad$ Received: 18.01 .2021 | Accepted: 01.02.2021 | Published: 04.02 .2021

*Corresponding author: Ashish Poudel

Abstract

Irregularities are mainly categorized under the plan and vertical irregularity in IS 1893 (Part 1): 2016 along with precautions for design and analysis in case of occurrence of irregularities. In this paper, an effort is done to identify irregularities present in existing commercial cum residential building satisfying provisions of Indian Standard code, and the complications on the adaption of mitigating measures. It is concluded that re-entrant corner irregularity is rampant in residential apartments and a soft storey is likely with open parking floors and building with variation in storey heights. Also, the three-dimensional vertical analysis method is ambiguous to adopt and the use of equivalent diagonal strut is ineffective with current clauses. Furthermore, additional clarification of weak storey is requisite.

Keywords: Irregularity, re-entrant corners, soft storey, weak storey.

Copyright (C) 2020 The Author(s): This is an open-access article distributed under the terms of the Creative Commons Attribution 4.0 International License (CC BY-NC 4.0) which permits unrestricted use, distribution, and reproduction in any medium for non-commercial use provided the original author and source are credited.

\section{INTRODUCTION}

Irregularity in mass or stiffness in plan and elevation makes a building more vulnerable in case of stability and lateral load resistance. Irregularity hinders uniformity of load path which may cause severe damage in the irregular building than a regular building. So efforts should be done to eliminate irregular configuration by modifying architectural planning. But sometimes irregularities are inevitable so IS 1893(Part 1) has defined types of them with criteria for consideration and some remedial measures are included in 2016 revisions [2]. Irregularities are categorized under Plan and Vertical irregularity. Torsion, Reentrant corner, Diaphragm Discontinuity, Out-of-Plane Offsets, and Non-Parallel systems are five types of plan irregularities. Additionally, Stiffness, Mass, Vertical Geometric, In-Plane Discontinuity in Vertical Elements Resisting Lateral Force, and Strength Irregularity are defined under Vertical Irregularity in 2002 revision of IS 1893 (Part 1) [1]. Whereas two more kinds of irregularities namely Floating or Stub Columns and Irregular modes of Oscillation in Two Principal Plan Directions are added under Vertical Irregularity in 2016 revision and Diaphragm discontinuity is defined as Floor slabs having excessive cut-outs or opening.

Condition for the existence of some irregularities is revised mainly for Torsional Irregularity, Stiffness, Mass, Strength, Vertical
Geometric, and In-Plane discontinuity. An irregularity check is performed for both the conditions mentioned as per the 2002 and 2016 revision.

Results from the equivalent static method are not appropriate in comparison to the response spectrum method as it doesn't consider irregularity effects and depends only on the empirical formula [3]. Buildings with complex shape should be designed duly taking care of their dynamic behavior [4]. Shorter structures with increased first storey height and taller structures with increased middle storey height generally produce greater inter-storey drift demands than regular storey [5]. Irregularities influences the height wise variation of story drifts with the effect of strength being larger than stiffness [6]. A requirement of Dynamic analysis for irregular buildings as per UBC is validated as Static analysis underestimates the column demands [7]. Distributions of total story shears were reproduced slightly more accurately by the dynamic methods than by the static methods [8].

\section{Building Configuration}

An existing seventeen storey multipurpose Tall building ( 2 Parking +2 Commercial +13 Residential) was considered to study the irregularities that may present in the building and to analyze provisions of the code on addressing those irregularities. Irregularities checks were performed as per both the revisions of IS 1893 (Part 1) and discussions are done based on the 
procedures of quantification of irregularity, measures to be taken, and the discrepancies present in the code.

One of the parking floors was maintained at $3.96 \mathrm{~m}$ so that it would be easy for parking and all the other floors are $3.05 \mathrm{~m}$. Residential floors are planned to maintain proper ventilation and lighting inside the room. Beam layouts of commercial and parking floors are identical whereas changed for residential floors. Dead loads and live loads on each floor are considered as per as per IS 875 (Part 1) and IS 875 (Part 2). The building was analyzed for earthquake loads for the load combinations as per IS 456: 2000. Beam layouts of commercial parking and residential floors are as shown in Fig 1 and 2. And the three dimensional rendered view of the building is shown in Fig-3.

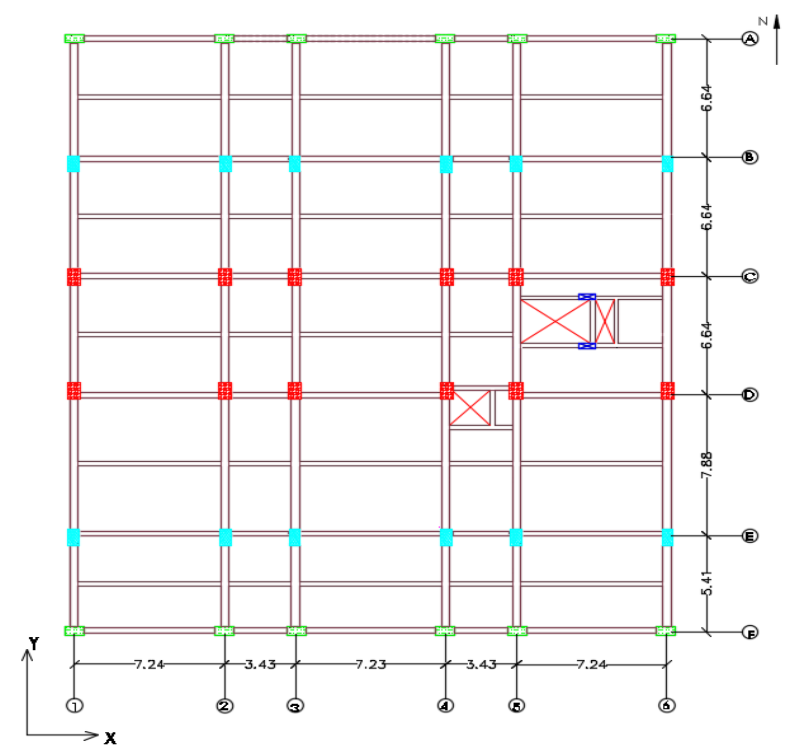

Fig-1: Beam layout of Commercial and Parking floor

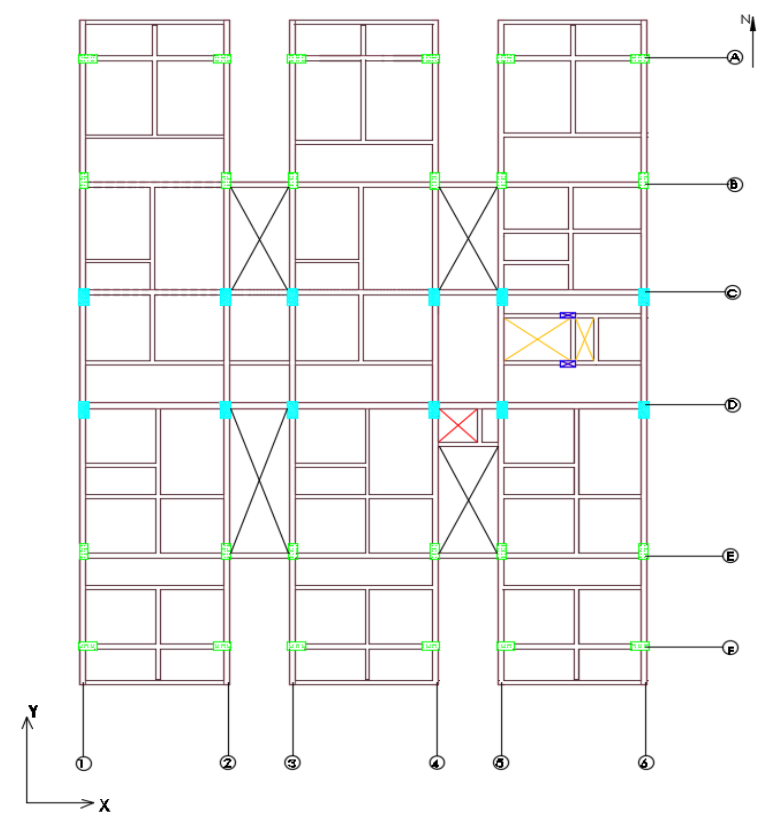

Fig-2: Beam layout of Residential floor

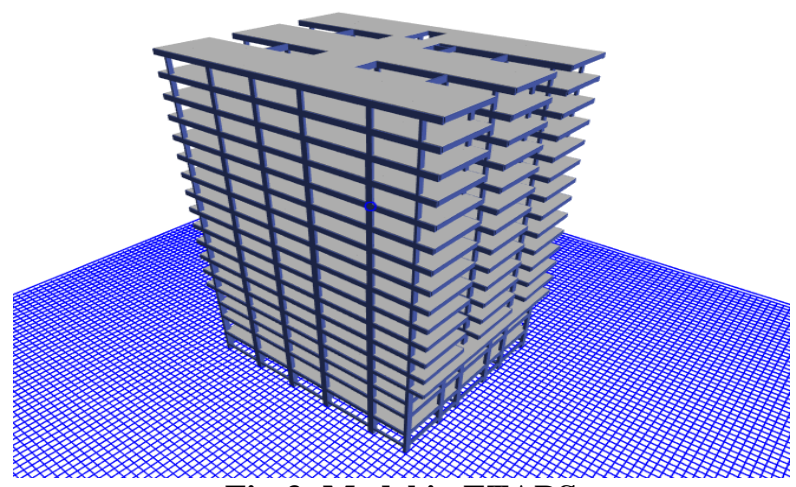

Fig-3: Model in ETABS

\section{Irregularity Check}

Irregularity in the building causes the ununiform distribution of mass and stiffness in plan and elevation which may cause damage. Irregularities and requirements to cope with them are mentioned in Table 5 and $6[1,2]$. All the irregularity conditions are checked to identify if any present in the building. Also, irregularity is verified as per IS 1893 (Part 1): 2002.

\section{Plan Irregularity}

\section{Torsional Irregularity}

For displacement

Irregularity is said to exist if the displacement of one end of the floor is 1.5 times its minimum horizontal displacement of the far end [2] while the ratio is 1.2 for the same [1].

a. In X-Direction b. In Y -Direction

$\mathrm{x}_{1}=67.7 \mathrm{~mm}$ and $\mathrm{x}_{2}=66.8 \mathrm{y}_{1}=58.6 \mathrm{~mm}$ and $\mathrm{y}_{2}=59.8$ Ratio $\left(\mathrm{x}_{1} / \mathrm{x}_{2}\right)=1.01<1.5^{2}$ ratio $\left(\mathrm{y}_{2} / \mathrm{y}_{1}\right)=1.02<$ $1.5^{2}$

$$
=1.01<1.2^{1}=1.02<1.2^{1}
$$

\section{For Natural Period}

Irregularity exists if the time period of fundamental torsional mode is greater than that of the first two translational modes [2]. The time period for the respective fundamental modes is given in Table-1.

Table-1: Modes with the respective time period

\begin{tabular}{|l|l|}
\hline Mode & Period $(\mathrm{sec})$ \\
\hline 1 (Translation) & 2.332 \\
\hline 2 (Translational) & 2.285 \\
\hline 3 (Torsional) & 2.095 \\
\hline
\end{tabular}

Natural period in fundamental torsional mode = $2.095 \mathrm{sec}<2.332 \mathrm{sec}$,

$=2.095 \mathrm{sec}<2.285 \mathrm{sec}$

As both the requirements are not satisfied Torsional irregularity is not present in the building

\section{Re-entrant Corners}

The re-entrant corner is said to exist if a projection of size greater than $15 \%$ of its overall plan dimension in that direction $[1,2]$. 


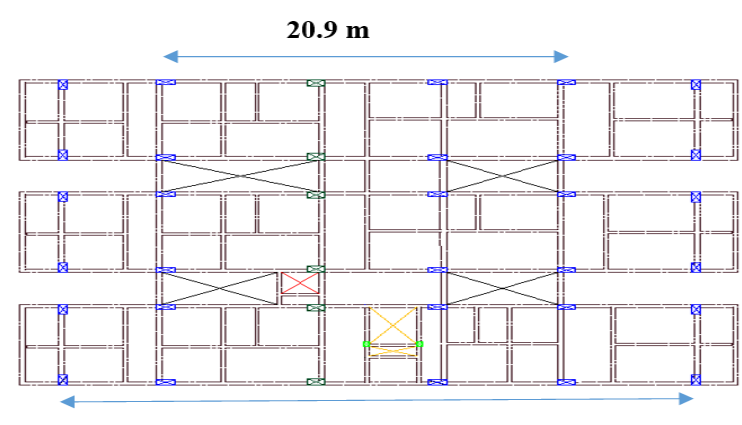

$37.5 \mathrm{~m}$

Fig-4: Beam layout of building with dimension for a re-entrant corner

From Fig-4 projection of $20.9 \mathrm{~m}$ is observed for a span of $37.5 \mathrm{~m}$.

So, Projection percentage $=(20.9 / 37.5) * 100=55.7 \%>$ $15 \%$

Re-entrant corner exists in building hence threedimensional dynamic analysis shall be adopted.

Floor slabs having excessive Cut-outs or Opening considered.

No such openings are present in the building

\section{Out-Of-Plane Offsets in Vertical Elements}

Offsets in vertical Elements are not present in building Considered.

\section{Non-Parallel Lateral Force System}

Irregularity is said to exist if all the structural systems resisting lateral forces are not oriented along two principal orthogonal axes in the plan. As shown in Fig-5. All the lateral load resisting elements i.e. Columns are oriented in two principal orthogonal directions in the building considered as shown in Fig-6. So the irregularity is not present in the building considered.

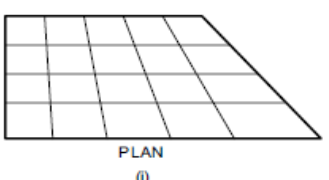

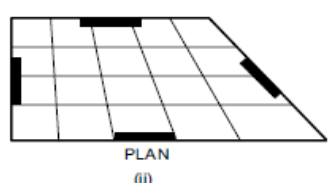

Fig-5: Non-Parallel lateral force system

Table-2: Lateral Stiffness calculation of Parking Floor

\begin{tabular}{|c|c|c|c|c|c|c|c|}
\hline $\begin{array}{c}\text { Column } \\
\text { Sizes } \\
(\mathrm{mm})\end{array}$ & No. & $\begin{array}{c}\mathrm{Ixx} \\
\left(\mathrm{mm}^{4}\right)\end{array}$ & $\begin{array}{c}\mathrm{Iyy} \\
\left(\mathrm{mm}^{4}\right)\end{array}$ & $\begin{array}{c}\mathrm{E} \\
\left(\mathrm{N} / \mathrm{mm}^{2}\right)\end{array}$ & $\begin{array}{c}\mathrm{H} \\
(\mathrm{mm})\end{array}$ & $\begin{array}{c}\mathrm{K} \times \\
(\mathrm{N} / \mathrm{mm})\end{array}$ & $\begin{array}{c}\mathrm{Ky} \\
(\mathrm{N} / \mathrm{mm})\end{array}$ \\
\hline $910 \times 460$ & 6 & 173321330000 & 44287880000 & 27386 & 3960 & 917230 & 234375 \\
\hline $910 \times 530$ & 6 & 67739035000 & 199696315000 & 27386 & 3960 & 358480 & 1056809 \\
\hline $910 \times 610$ & 6 & 103276355000 & 229839155000 & 27386 & 3960 & 546547 & 1216327 \\
\hline $910 \times 610$ & 6 & 103276355000 & 229839155000 & 27386 & 3960 & 546547 & 1216327 \\
\hline $910 \times 530$ & 6 & 67739035000 & 199696315000 & 27386 & 3960 & 358480 & 1056809 \\
\hline $910 \times 460$ & 6 & 173321330000 & 44287880000 & 27386 & 3960 & 917230 & 234375 \\
\hline & & & & & Total & 3644515 & 5015022 \\
\hline
\end{tabular}


Table-3: Lateral Stiffness calculation of Commercial Floor

\begin{tabular}{|c|c|c|c|c|c|c|c|}
\hline $\begin{array}{c}\text { Column } \\
\text { Sizes } \\
(\mathrm{mm})\end{array}$ & No. & $\begin{array}{c}\mathrm{I} \times \mathrm{xx} \\
\left(\mathrm{mm}^{4}\right)\end{array}$ & $\begin{array}{c}\mathrm{I} \mathrm{yy} \\
\left(\mathrm{mm}^{4}\right)\end{array}$ & $\begin{array}{c}\mathrm{E} \\
\left(\mathrm{N} / \mathrm{mm}^{2}\right)\end{array}$ & $\begin{array}{c}\mathrm{H} \\
(\mathrm{mm})\end{array}$ & $\begin{array}{c}\mathrm{K} \times \\
(\mathrm{N} / \mathrm{mm})\end{array}$ & $\begin{array}{c}\mathrm{Ky} \\
(\mathrm{N} / \mathrm{mm})\end{array}$ \\
\hline $910 \times 460$ & 6 & 173321330000 & 44287880000 & 27386 & 3050 & 2007541 & 512976 \\
\hline $910 \times 530$ & 6 & 67739035000 & 199696315000 & 27386 & 3050 & 784606 & 2313036 \\
\hline $910 \times 610$ & 6 & 103276355000 & 229839155000 & 27386 & 3050 & 1196226 & 2662174 \\
\hline $910 \times 610$ & 6 & 103276355000 & 229839155000 & 27386 & 3050 & 1196226 & 2662174 \\
\hline $910 \times 530$ & 6 & 67739035000 & 199696315000 & 27386 & 3050 & 784606 & 2313036 \\
\hline $910 \times 460$ & 6 & 173321330000 & 44287880000 & 27386 & 3050 & 2007541 & 512976 \\
\hline & & & & & Total & 7976745 & 10976373 \\
\hline
\end{tabular}

Table-4:Error! No text of specified style in document. Lateral Stiffness calculation of Residential Floor

\begin{tabular}{|c|c|c|c|c|c|c|c|}
\hline $\begin{array}{c}\text { Column } \\
\text { Sizes } \\
(\mathrm{mm})\end{array}$ & No. & $\begin{array}{c}\mathrm{Ixx} \\
\left(\mathrm{mm}^{4}\right)\end{array}$ & $\begin{array}{c}\mathrm{I} \text { yy } \\
\left(\mathrm{mm}^{4}\right)\end{array}$ & $\begin{array}{c}\mathrm{E} \\
\left(\mathrm{N} / \mathrm{mm}^{2}\right)\end{array}$ & $\begin{array}{c}\mathrm{H} \\
(\mathrm{mm})\end{array}$ & $\begin{array}{c}\mathrm{K} \mathrm{x} \\
(\mathrm{N} / \mathrm{mm})\end{array}$ & $\begin{array}{c}\mathrm{Ky} \\
(\mathrm{N} / \mathrm{mm})\end{array}$ \\
\hline $910 \times 460$ & 6 & 173321330000 & 44287880000 & 27386 & 3050 & 2007541 & 512976 \\
\hline $910 \times 460$ & 6 & 44287880000 & 173321330000 & 27386 & 3050 & 512976 & 2007541 \\
\hline $910 \times 530$ & 6 & 67739035000 & 199696315000 & 27386 & 3050 & 784606 & 2313036 \\
\hline $910 \times 530$ & 6 & 67739035000 & 199696315000 & 27386 & 3050 & 784606 & 2313036 \\
\hline $910 \times 460$ & 6 & 44287880000 & 173321330000 & 27386 & 3050 & 512976 & 2007541 \\
\hline $910 \times 460$ & 6 & 173321330000 & 44287880000 & 27386 & 3050 & 2007541 & 512976 \\
\hline & & & & & Total & 6610246 & 9667107 \\
\hline
\end{tabular}

Stiffness irregularity is checked for three different floor levels as shown in Fig-7 for which lateral stiffness is calculated as shown in Tables 2, 3 and 4 for parking, commercial and residential floor respectively. Lateral stiffness of parking floor (Kp) with height $3.96 \mathrm{~m} \mathrm{Kp}=3644514.5 \mathrm{kN} / \mathrm{m}$

Lateral Stiffness of commercial floor $(\mathrm{Kc})$ with height $3.05 \mathrm{~m} \mathrm{Kc}=7976745.3 \mathrm{kN} / \mathrm{m}$ Lateral Stiffness of Residential floor $(\mathrm{Kr})$ with height $3.05 \mathrm{~m} \mathrm{Kr}=$ $6610245.6 \mathrm{kN} / \mathrm{m}$

Lateral Stiffness of commercial floor $\mathrm{Kc}>\mathrm{Kp}$ Lateral stiffness of parking floor. Also $\left(\mathrm{K}_{\mathrm{p}} / \mathrm{K}_{\mathrm{c}}\right) \times 100=45 \%<$ $70 \%$

So there is stiffness irregularity between Parking and commercial floor as per both revisions. But $\mathrm{Kr}<\mathrm{Kc}$ so Stiffness irregularity does not exist between commercial and residential floor.

\section{Mass Irregularity}

Mass irregularity shall be considered to exist when the seismic weight of any floor is more than 150 $\%$ [2] and 200\% [1] of that of the floors below respectively as shown in Fig-8.

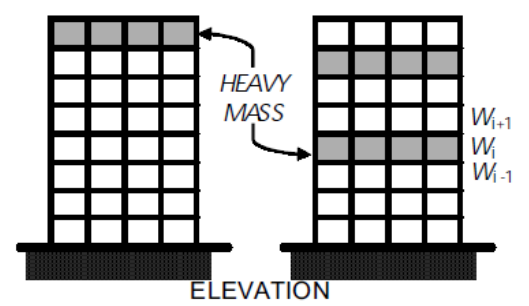

$W_{\mathrm{i}}>1.5 W_{\mathrm{i}+1}$ $W_{\mathrm{i}}>1.5 W_{\mathrm{i}-1}$

Fig-8: Indication for Mass Irregularity

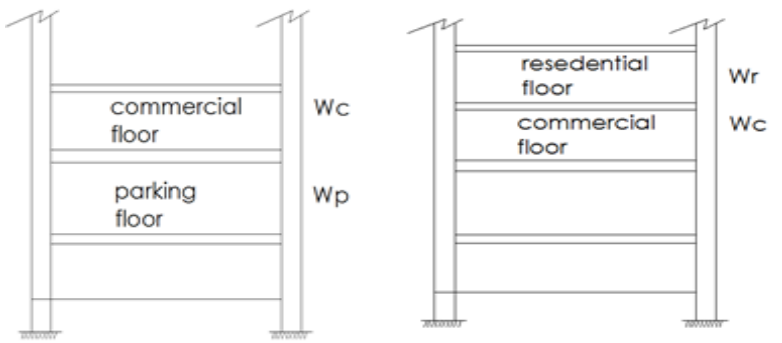

Fig-9: Section of elevation indicating different types of floors

Seismic weight is calculated for three different floors as shown in Fig-9 whose loads are different from one another and compared for the presence of mass irregularity.

Seismic weight of the commercial floor $\mathrm{Wc}=10951.7$ $\mathrm{kN}$ and

Seismic weight of the parking floor $\mathrm{Wp}=10669.5 \mathrm{kN}$ Percentage seismic weight of commercial floor $=102.6 \%<150 \%<200 \%$.

So mass irregularity is not present between the commercial and parking floor.

The seismic weight of the commercial floor $\mathrm{Wc}=$ $10951.7 \mathrm{kN}$

Seismic weight of residential floor $\mathrm{Wr}=13026.8 \mathrm{kN}$

Percentage seismic weight of residential floor $=118.9$ $\%<150 \%$ and $<200 \%$.

So mass irregularity is not present between the commercial and residential floor.

\section{Vertical Geometric Irregularity}

Irregularity is said to exist if the Horizontal Dimension of lateral load force-resisting system in any 
storey is more than $125 \%$ and $150 \%$ of the storey below $[2,1]$. No such projection is present in building considered.

\section{In-Plane Discontinuity in Vertical Elements Resisting Lateral Force \\ Irregularity exists if In-Plane offset of the lateral force-resisting elements is greater than $20 \%$ of the plan length of that element [2] while 2002 revision has not fixed the percentage [1]. No such offset in lateral force resisting element is present in the building considered.}

\section{Strength Irregularity (Weak Storey)}

The storey weak in stiffness can also be considered weak in strength thus strength irregularity exists in the building. As the lateral load resisting members are the same in the floors there seems no distinct way defines by the standard to determine the strength.

\section{Floating or Stub Column}

Such columns are not present in the building considered.

\section{Irregular Modes of Oscillation in Two Principal Plan Direction}

Irregularity of Irregular modes of Oscillation is newly mentioned provision in latest revision [2].

a. First three modes contribute less than $65 \%$ mass participation factor in each principal plane. Mass participation for all three fundamental modes is presented in Table 5.

Table-5: Mass participation in Different modes

\begin{tabular}{|l|l|l|}
\hline No of Mode & Mass participation factor in $\mathbf{x}$ & Mass participation factor in $\mathbf{y}$ \\
\hline $\mathbf{1}$ & 0.801 & $4.165 \mathrm{E}-06$ \\
\hline $\mathbf{2}$ & $4.469 \mathrm{E}-06$ & 0.8437 \\
\hline $\mathbf{3}$ & $9.144 \mathrm{E}-06$ & 0.0038 \\
\hline
\end{tabular}

Mass Participation factor in both orthogonal directions is $80.1 \%$ in $\mathrm{X}$ and $84.4 \%$ in $\mathrm{Y}>65 \%$.

b. fundamental lateral natural periods of the building in the two principal plan directions are closer to each other by $10 \%$ of the larger value.

Table-6: Modes with the respective time period

\begin{tabular}{|l|l|}
\hline No of Mode & Period $(\mathbf{s e c})$ \\
\hline $\mathbf{1}$ & 2.332 \\
\hline $\mathbf{2}$ & 2.285 \\
\hline
\end{tabular}

From Table-6 the percentage of difference in natural periods of fundamental modes is equal to:

$=(2.332-2.285) / 2.332 * 100$

$=2.02 \%<<10 \%$

As both, the requirement does not satisfy the irregularity is absent in the building considered.

Irregularities mentioned in Table 5 and 6 as per Cl. 7.1 are checked and namely Re-entrant Corner in plan and Stiffness Irregularity among Vertical Irregularities are present in the tall building considered. The re-entrant corner is present in all residential floors and vertical irregularity was present in the parking floor with a height of $3.96 \mathrm{~m}$.

\section{DISCUSSIONS ON CODE PROVISIONS}

Irregularities some times are inevitable like stiffness irregularity and Re-entrant corner as shown above in general or regular practiced buildings. The soft storey is susceptible when storey height is raised for parking or seminar hall and sometimes for movie theatre in commercial buildings. Likewise, Re-entrant corner irregularity seems widespread in residential apartment buildings as discontinuities are must for lighting and ventilation purposes i.e. for windows

\section{Remedial Measures}

The 20162 revision of IS 1893 (Part 1) has mentioned the methods to deal with irregularities and their limitations.

\section{Vertical Earthquake Effects}

Consideration of vertical ground shaking has been suggested in $\mathrm{Cl}$. 6.3.3.1 for structures located in Zone IV or $\mathrm{V}$ and also if the structure has vertical or plan irregularity along with other requisites. Though the load combinations and considerations of the amount of load factor are specified together with design seismic acceleration spectral value Av the adoption of vertical shaking in the conditions specified seems vague. So, code provisions should clarify the procedures for the application of vertical earthquake effect for unavoidable.

\section{Re-Entrant Corner}

Irregularity in plan mostly in residential apartment buildings is present for ventilation and lighting as shown in the above inspection of irregularity in the considered building. Three- dimensional dynamic analysis is recommended to cope with a re-entrant corner in 2016 revision in addition to the $\mathrm{Cl}$. 6.3.3.1 about vertical earthquake effects and $\mathrm{Cl}$ 7.7.1 requirement of linear dynamic analysis for any irregular building. Which leaves a query that is it a necessity for vertical earthquake and dynamic analysis for apartment buildings of height around $15 \mathrm{~m}$ also because the reentrant corner appears to be unavoidable. 


\section{Vertical Irregularity (Soft Storey)}

The soft storey is caused mainly due to increased storey height or open storey. Both 20021 and 20162 revisions have recommended some measures as

i. Placement of RC structural wall with proper foundation and connection with moment resisting frame which is only possible for a soft or open storey in the ground floor or so. But for the case of occurrence of a soft storey in upper floors for seminar halls or movie theatre shear wall is absurd which if provided also causes difficulties for practical implication and certainly will increase stiffness beyond the lower storey which again makes a lower storey a soft storey or should be provided throughout the height of the building which increases the cost of construction.

ii. Braced frame in selected bays of the building, which increases the lateral stiffness of the soft storey. In doing so additional torsion may occur because of limited stiffer bays and also stiffness should be checked not to be much larger than a lower storey which in turn creates another soft storey below that floor.

iii. Equivalent Diagonal Strut for Unreinforced Masonry Infill Walls in RC Frame.

Other than above-mentioned provisions 20162 revision recommends the estimation of stiffness contribution by Unreinforced Masonry URM infill by the introduction of an Equivalent Diagonal Strut in the analysis to address the additional stiffness and strength provided by infill.

A sample wall section was considered to check for the possibility of an equivalent diagonal strut as per Cl. 7.9 of IS 1893 (Part 1): 2016 as shown in Fig-10.

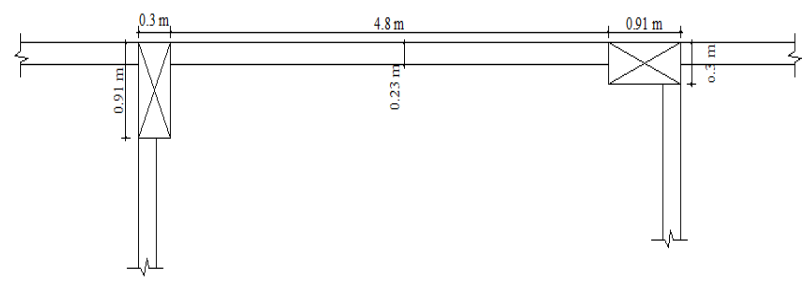

Fig-10: Portion of wall and column arrangement under consideration

Clear length of wall $=4.8 \mathrm{~m}$

The thickness of wall $=0.23 \mathrm{~m}$

Storey height $=3.05 \mathrm{~m}$

Column section $=910 \mathrm{~mm} \times 300 \mathrm{~mm}$

Beam Section $=300 \mathrm{~mm} \times 600 \mathrm{~mm}$

Clear height $\mathrm{h}=3.05-0.6=2.45 \mathrm{~m}$

Width of equivalent diagonal strut $w_{d s}=0.175 \alpha_{h}^{-0.4} L_{d s}$

Where, $\alpha_{h}=h\left(\sqrt[4]{\frac{E_{m} t \sin 2 \theta}{4 E_{f} I_{c} h}}\right)$ and Lds = diagonal

length

$$
\begin{aligned}
& I c_{1}=\frac{920 \times 310^{3}}{12}=2.28 \times 10^{9} \mathrm{~mm}^{4} \\
& I c_{2}=\frac{310 \times 920^{3}}{12}=2.011 \times 10^{10} \mathrm{~mm}^{4} \\
& \mathrm{Lds}=\sqrt{2.45^{2}+4.84^{2}}=5.42 \mathrm{~m} \\
& \theta=\tan ^{-1} \frac{2.45}{4.84}=26.85^{\circ}
\end{aligned}
$$

Now, $\mathrm{Em}=f_{m} 550$

$f_{m}=0.433 f_{b}^{0.64} f_{m o}^{0.36}=$

$0.433 \times 3^{0.64} \times 5^{0.36}=1.5613$

$\mathrm{Em}=550 \times 1.5613=858.692 \mathrm{~N} / \mathrm{mm}^{2}$

$\mathrm{Ef}=5000 \sqrt{f_{c k}}=25000 \mathrm{~N} / \mathrm{mm}^{2}$

$I c_{1}=\frac{920 \times 310^{3}}{12}=2.28 \times 10^{9} \mathrm{~mm}^{4}$

$I c_{2}=\frac{310 \times 920^{3}}{12}=2.011 \times 10^{10} \mathrm{~mm}^{4}$

Now solving for $\alpha_{h}=1.20$

Width of equivalent diagonal strut $w_{d s}=0.175 \alpha_{h}^{-0.4} L_{d s}$

$=0.175 \times 1.20-0.4 \times 5420$

$=881.59 \mathrm{~mm}$

For the requirements of height to thickness and length to thickness ratios $($ Cl.7.9.2.2, $\mathrm{d})$

$\mathrm{h} / \mathrm{t}=2450 / 228.6=10.72<12 \ldots \ldots . \mathrm{Ok}$

$1 / \mathrm{t}=4840 / 228.6=21.17>12 \ldots \ldots \ldots$. not ok

If the thickness of the wall is $115 \mathrm{~mm}$

$\mathrm{h} / \mathrm{t}=2450 / 115=21.30>12$

So, to satisfy the conditions of $1 / t<12$

$1<12 \times 115=1038 \mathrm{~mm}$ for $115 \mathrm{~mm}$ wall and

$1<12 \times 230=2760 \mathrm{~mm}$ for $230 \mathrm{~mm}$ wall

Hence the requirement could not be satisfied so Equivalent Diagonal Strut could not be placed in the analysis. Which makes the provision questionable for its purpose if we can't adapt it for more than $3 \mathrm{~m}$ clear span for $230 \mathrm{~mm}$ wall and, it is unlikely to consider the use of strut in $115 \mathrm{~mm}$ wall.

\section{Stiffness and Strength Irregularity}

Stiffness is the force needed to cause a unit deflection and can be calculated as the slope of forcedisplacement whereas strength is a total force that a system can resist. Though both irregularities are differently defined in IS 1893 (Part 1) both seems to be very closely interrelated as the storey with stiffness irregularity likely to be a week in lateral strength too. Furthermore, code has undefined how can we quantify week storey as there is ambiguity on the procedure to calculate lateral strength. So there is a need for clarification about the presence of soft and week storey 
whether can exist independently or co-exist in a building.

\section{RESULTS}

1. Irregularity of Re-entrant corners is present for lighting and ventilation purpose in apartment buildings regardless of their height.

2. Soft storey present in the building is most likely if the variation of the height of storey is done.

3. Three-dimensional dynamic analysis procedure and consideration required to be more distinctly described.

4. Recommended use of equivalent diagonal strut for unreinforced masonry infill wall cannot be effectively accomplished satisfying the current provision of height to thickness and length to thickness ratios.

5. Strength irregularity and approach of its determination should be further defined along with its occurrence with and without the soft story.

\section{REFERENCES}

1. Indian Standard Criteria for Earthquake Resistant Design of Structures, IS 1893 (Part 1): 2002, Bureau of Indian Standards, New Delhi.

2. Indian Standard Criteria for Earthquake Resistant Design of Structures, IS 1893 (Part 1): 2016, Bureau of Indian Standards, New Delhi.

3. Ravikumar, C. M., Babu Narayan, K. S., Sujith, B. V., \& Venkat Reddy, D. (2012). Effect of irregular configurations on seismic vulnerability of RC buildings. Architecture Research, 2(3), 20-26.

4. Gupta, A., \& Kumar, A. (2012). Study of Response of Structurally Irregular Building
Frames to Seismic Excitations. International Journal of Civil, Structural, Environmental and Infrastructure Engineering Research and Development (IJCSEIERD), 2(2), 25-31.

5. Sadashiva, V. K., MacRae, G. A., \& Deam, B. L. (2011). Effects of coupled vertical stiffnessstrength irregularity due to modified interstorey height. Bulletin of the New Zealand Society for Earthquake Engineering, 44(1), 31-44.

6. Chintanapakdee, C., \& Chopra, A. K. (2004). Seismic response of vertically irregular frames: response history and modal pushover analyses. Journal of Structural Engineering, 130(8), 1177-1185.

7. Pong, W., \& Nesbet, D. (2002, January). Design implications of structural irregularity. In ASME Pressure Vessels and Piping Conference (Vol. 46563, pp. 209-213).

8. Moehle, J. P., \& Alarcon, L. F. (1986). Seismic analysis methods for irregular buildings. Journal of Structural Engineering, 112(1), 35-52.

9. Indian Standard Code of Practice for Design Loads (Other than Earthquake) for Buildings and Structures - Dead Loads - Unit weight of building materials and stored materials, IS 875 (Part 1): 1987, Bureau of Indian Standards, New Delhi.

10. Indian Standard Code of Practice for Design Loads (Other than Earthquake) for Buildings and Structures - Imposed loads, IS 875 (Part 2): 1987, Bureau of Indian Standards, New Delhi.

11. Indian Standard Plain and Reinforced ConcreteCode of Practice, IS 456: 2000, Bureau of Indian Standards, New Delhi. 